\title{
Rapid detection of medium chain acyl-CoA dehydrogenase gene mutations by non-radioactive, single strand conformation polymorphism minigels
}

Achille Iolascon, Teresa Parrella, Silverio Perrotta, Ornella Guardamagna, Paul M Coates, Maria Sartore, Saul Surrey, Paolo Fortina

\begin{abstract}
Medium chain acyl-CoA dehydrogenase (MCAD) deficiency is a common inherited metabolic disorder affecting fatty acid $\beta$ oxidation. Identification of carriers is important since the disease can be fatal and is readily treatable once diagnosed. Twelve molecular defects have been identified in the MCAD gene; however, a single highly prevalent mutation, A985G, accounts for $>90 \%$ of mutant alleles in the white population. In order to facilitate the molecular diagnosis of MCAD deficiency, oligonucleotide primers were designed to amplify the exon regions encompassing the 12 mutations enzymatically, and PCR products were then screened with a single strand conformation polymorphism (SSCP) based method. Minigels were used allowing much faster run times, and silver staining was used after gel electrophoresis to eliminate the need for radioisotopic labelling strategies. Our non-radioactive, minigel SSCP approach showed that normals can be readily distinguished from heterozygotes and homozygotes for all three of the 12 known MCAD mutations which were detected in our sampling of 48 persons. In addition, each band pattern is characteristic for a specific mutation, including those mapping in the same PCR product like A985G and T1124C. When necessary, the molecular defect was confirmed using either restriction enzyme digestion of PCR products or by direct DNA sequence analysis or both. This rapid, non-radioactive approach can become routine for molecular diagnosis of MCAD deficiency and other genetic disorders.
\end{abstract}

( $($ Med Genet 1994;31:551-554)

MCAD deficiency is a common inherited autosomal recessive disorder of mitochondrial fatty acid oxidation with a frequency approaching 1 in 10 to 20000 white infants. ${ }^{1-3}$ Therefore, approximately 1 in 50 to 70 persons should be carriers for the disease. It presents usually within the first two years of life with fasting associated hypoketotic hypoglycaemia which may lead to coma and death. Occasionally, patients have a single episode without warning which is fatal; these cases are often diagnosed as sudden infant death syndrome (SIDS) ${ }^{4-7}$ Treatment of MCAD deficiency is based on avoidance of fasting and glucose infusion during the episode.

Since MCAD deficiency appears to be relatively common with variable clinical presentation and is readily treatable once diagnosed, it is important to recognise carriers and suspected cases. Diagnosis can be achieved by measurement of cis-4-decenoic acid by gas chromatography mass spectrometry or by direct detection of acyl-carnitine. ${ }^{8-13} \mathrm{~A}$ more accessible technique for many laboratories involves PCR based molecular analysis. The MCAD gene comprises 12 exons which span $55 \mathrm{~kb}$ of DNA. ${ }^{14}$ Ten single base changes, one insertion, and one deletion have been reported to date: eight are clustered in exon 11 (T977C, A985G, a 13 bp tandem repeat insertion at position 999, T1008A, C1045T, a 4 bp deletion encompassing position 1100-1103, T1124C and A1161G), two in exon 9 (T730C and G799A), and one each in exon 6 (G447A) and exon $3(\mathrm{C} 157 \mathrm{~T}){ }^{16-18}$ The $A$ to $G$ transition at nucleotide 985 in exon 11 of the MCAD gene accounts for $>90 \%$ of the mutant alleles characterised in white populations with MCAD deficiency while some alleles $(7 \cdot 8 \%)$ are still unidentified. ${ }^{19}$

Different molecular methods are in use to detect mutations causing MCAD: modified PCR/restriction digestion, allele specific PCR (ASPCR), and allele specific oligohybridisation (ASO). Screening for the A985G mutation is generally performed by PCR using a forward primer which creates an NcoI restriction site in the mutant, but not the normal allele. Resultant PCR products are then subjected to $N c o$ I digestion followed by electrophoresis on native agarose gels. ${ }^{20}$ This approach allows detection of the most common mutation in white populations; however, it leaves other MCAD defects undetected. Since the incidence of MCAD deficiency is relatively high in the northern European population, a rapid screening strategy is needed to establish frequency and mutation heterogeneity. Furthermore, neonatal screening is particularly useful since symptoms can be prevented by appropriate management.

Methods and results

We devised a rapid SSCP based method which identifies at least three of the 12 known mutations. SSCP analysis is an important approach 
for detection of base changes in PCR products, and has been recently used to distinguish DR4 alleles for determination of HLA compatibility. ${ }^{2122}$ The technique is based on the principle that under non-denaturing conditions the electrophoretic mobility of single stranded nucleic acid depends not only on size but also DNA sequence. ${ }^{23} \mathrm{We}$ present important modifications to the original SSCP protocol which facilitate rapid non-radioactive delineation of mutations causing disease. Our approach involves the use of minigels which also allows much faster run times, and silver nitrate staining for single stranded DNA detection which eliminates the need for radioisotopic labelling strategies. Pharmacia LKB Biotechnology (Alameda, CA) recently introduced a pre-cast gel system which uses a similar approach to mutation detection. Our protocol including PCR steps takes about four to six hours.

Forty-eight samples from white persons of northern Europe ancestry were referred to the Children's Hospital of Philadelphia for determination of MCAD deficiency. The majority of those tested were sibs or parents of children diagnosed with sudden infant death syndrome, from families with a history of MCAD disease, or had atypical profiles for excreted organic acids and enzymatic assays. Genomic DNA was extracted from peripheral blood leucocytes using previously described protocols. ${ }^{24}$ Four segments encompassing exons 3 and 4, exon 6 , exon 9, and exon 11 of the human MCAD gene were amplified using a DNA thermocycler as previously described. ${ }^{25}$ Oligoprimer sequences with MCAD gene coordinates and PCR product sizes are listed in the table. Amplifications were performed for 30 cycles in $100 \mu \mathrm{l}$ of reaction containing $300 \mathrm{ng}$ of genomic DNA, $6.7 \mathrm{mmol} / 1 \mathrm{MgCl}_{2}$, $16.6 \mathrm{mmol} / 1 \quad\left(\mathrm{NH}_{4}\right)_{2} \mathrm{SO}_{4}, \quad 5 \mathrm{mmol} / 1 \quad \beta M E$, $6.8 \mu \mathrm{mol} / 1$ EDTA, $67 \mathrm{mmol} / 1$ Tris $\mathrm{Cl} \mathrm{pH} 8.8$, $200 \mu \mathrm{mol} / 1 \mathrm{dNTP}, 0 \cdot 15 \mu \mathrm{mol} / 1$ primers, and 2.5 U AmpliTaq polymerase (Perkin Elmer Cetus, Norwalk, CT). Each cycle included the following denaturation, annealing, and Taq polymerase extension conditions: $94^{\circ} \mathrm{C}$ for 45 seconds, $60^{\circ} \mathrm{C}$ for 30 seconds, and $72^{\circ} \mathrm{C}$ for 45 seconds for exon 3, 4, and 9 amplifications; $95^{\circ} \mathrm{C}$ for one minute, $50^{\circ} \mathrm{C}$ for one minute, and $72^{\circ} \mathrm{C}$ for 1.5 minutes for exon 6 ; and $94^{\circ} \mathrm{C}$ for two minutes, $56^{\circ} \mathrm{C}$ for one minute and 30 seconds, $72^{\circ} \mathrm{C}$ for two minutes for exon 11 . Up to a maximum of $16 \mathrm{PCR}$ products $(8 \times 2$ minigels) can be electrophoresed on a nondenaturing minigel $(7.2 \mathrm{~cm} \times 10.2 \mathrm{~cm})$ (BioRad Laboratories, Melville, NY) containing $10-12 \%(w / v)$ acrylamide (acrylamide/bis $38: 1$ $(\mathrm{w} / \mathrm{w})$ ) and $5-10 \%(\mathrm{v} / \mathrm{v})$ glycerol. PCR product $(2 \mu \mathrm{l})$ is mixed with $10 \mu \mathrm{l}$ of denaturing solution $(95 \%(\mathrm{v} / \mathrm{v})$ formamide, $0.05 \%(\mathrm{w} / \mathrm{v})$ each of bromophenol blue and xylene-cyanol in $20 \mathrm{mmol} / 1 \mathrm{EDTA}$ ), samples are heated at $96^{\circ} \mathrm{C}$ for five minutes, cooled in a $4^{\circ} \mathrm{C}$ ice bath, and then electrophoresed in $1 \times$ TBE buffer at $4^{\circ} \mathrm{C}$ using $120-150$ volts for two to four hours. Visualisation of single stranded DNA was performed by standard silver nitrate staining (Bio-Rad Laboratories).

SSCP patterns for the different MCAD mutations are shown in the figure. All samples showing normal SSCP patterns were subjected to automated DNA sequence analysis and shown to have normal sequence in the PCR products of exons $3,4,9$, and 11 (data not shown). Two of the eight known mutations in exon 11 were detected in our samples using SSCP (lanes 2 and 3). The patterns for normal (N), A985G, and T1124C mutations were clearly different. Assignment of $\mathrm{N} / \mathrm{N}$ (figure, lane 1), A985G/A984G (lane 2), A985/T1124C (lane 3), and A985G/N genotypes (lane 5) in the 249 bp PCR product from exon 11 was confirmed either by digestion with $N c o$ I for A985G or $A c c \mathrm{I}$ for T1124C, as described previously. ${ }^{20}$ The only known mutation in exon 6 was also readily detected in our samples using SSCP (lanes 7 and 8). Patterns for normals (lane 6) and G447A (lane 8) were clearly resolved, and assignment of the G447A/N genotype (lane 8) in the $81 \mathrm{bp}$ PCR product from exon 6 was confirmed by digestion with $\mathrm{Mse} \mathrm{I}$ as described previously. These results corroborated by direct DNA sequence analysis of the PCR products suggest that this SSCP protocol has not missed detection of any other disease causing mutation in these MCAD gene exon regions in the samples we analysed. Results of our analysis of the 48 samples showed the following: 29 were negative for any of the 12 known mutations, and there were 11 heterozygotes and six homozygotes for A985G, one heterozygote for G447A, one compound heterozygote for A985G/ T1124C, and one for A985G/G447A. Further studies are in progress to analyse additional MCAD gene regions by SSCP for potential disease causing mutations in the remaining samples.

\section{Discussion}

This non-radioactive minigel SSCP approach can readily distinguish at least three of the 12 known MCAD disease causing mutations and may in fact distinguish the remaining known MCAD mutations. Additional samples containing the remaining nine mutations are now required to test this. In addition, each band pattern is characteristic for a specific mutation, including those mapping in the same PCR

Oligonucleotides used for genomic DNA amplification and DNA sequence analysis

\begin{tabular}{|c|c|c|c|c|}
\hline Primer & Sequence $5^{\prime}-3^{\prime}$ & Exon & $\begin{array}{l}P C R \\
\text { product } \\
\text { (bp })\end{array}$ & Coordinate* \\
\hline $\begin{array}{l}\text { MCAD-1-F } \\
\text { MCAD-2-R } \\
\text { MCAD-3-F } \\
\text { MCAD-4-R } \\
\text { MCAD-5-F } \\
\text { MCAD-6-R } \\
\text { MCAD-7-F } \\
\text { MCAD-8-R }\end{array}$ & $\begin{array}{l}\text { AGTTCACCGAACAGCAGA } \\
\text { TTCCCAGGCTCTTCTAATTAG } \\
\text { CAAATGCCTATTATTATT } \\
\text { ACACATCAATGGCTCTC } \\
\text { GAATTAAACATGGGCCA } \\
\text { TACAGGTCTGGTTTTATCAAA } \\
\text { CACCAAGCAATATCATTTATG } \\
\text { CTGATAGATTTTGGCATCCCT }\end{array}$ & $\begin{array}{l}3 \text { and } 4 \\
6 \\
9 \\
11\end{array}$ & $\begin{array}{r}202 \\
81 \\
141 \\
249\end{array}$ & $\begin{array}{l}119-136 \\
229-249 \\
388-405 \\
451-468 \\
709-725 \\
829-849 \\
946-966 \\
1174-1194\end{array}$ \\
\hline
\end{tabular}

* Coordinates refer to published sequence of the MCAD gene. ${ }^{14}$ 


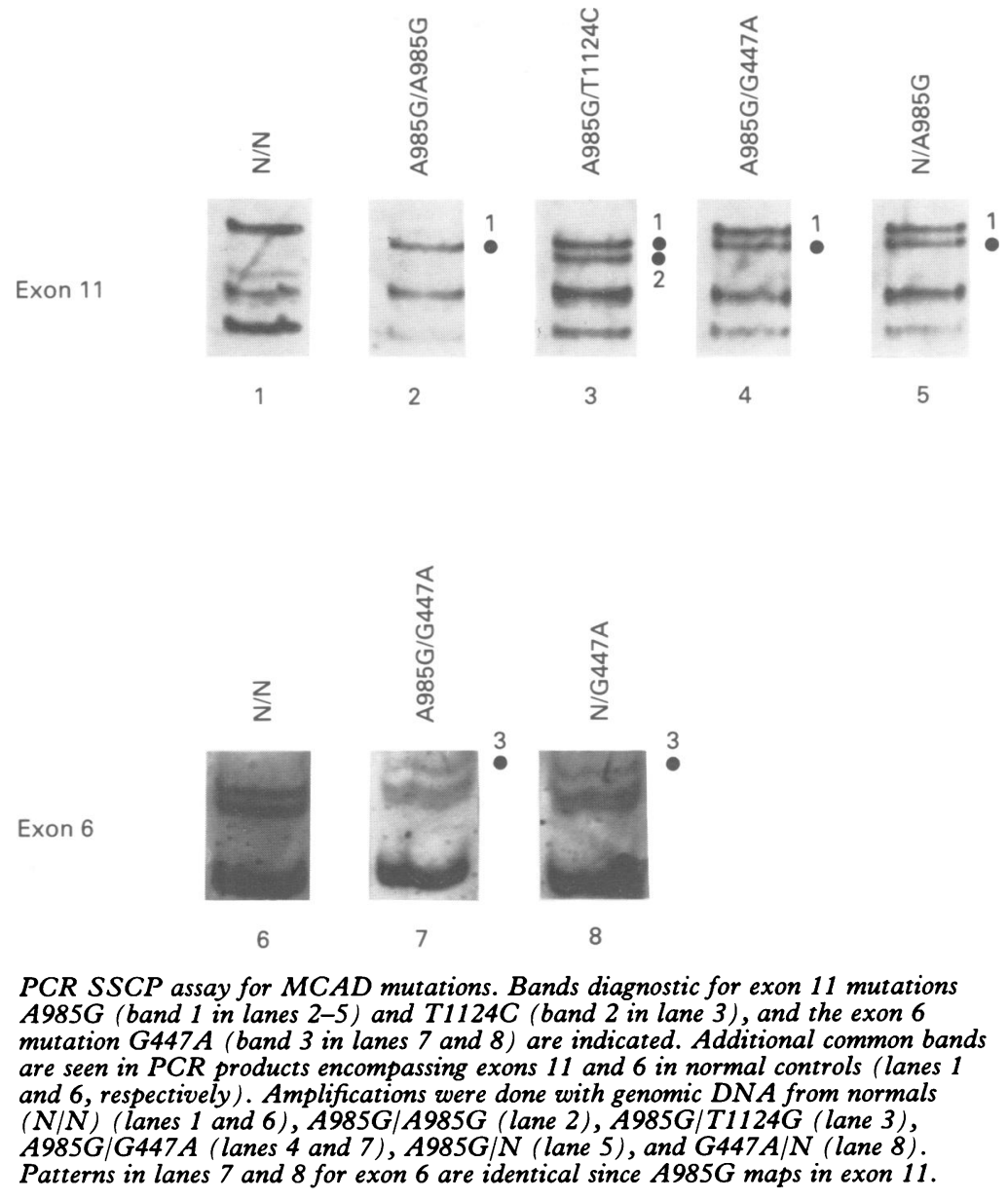

product as evidenced by different patterns for A985G and T1124C in exon 11 (figure, compare lanes 2 and 3, and lanes 3 and 5). Band patterns differing from those described in this report can be further characterised by direct DNA sequence analysis to define the mutation. This SSCP method is rapid, simple, reliable, cost effective, and capable of detecting disease causing mutations in the MCAD gene, and is a good first step in targeting regions for further DNA sequence analysis.

This work was supported in part by a grant from the Ethel Brown Foerderer Fund for Excellence (PF). TP is a recipient of the SEEDS for SID Research Fellowship.

1 Roe CR, Coates PM. Acyl CoA dehydrogenase deficiencies. In: Scriver CR, Beaudet AL, Sly WS, Valley D, eds. The metabolic basis of inherited diseases. 6th ed. New York: McGraw-Hill, 1989:889-914.

2 Yokota Y, Coates PM, Hale DE, et al. Molecular survey of a prevalent mutation, ${ }^{985} \mathrm{~A}-\mathrm{to}-\mathrm{G}$ transition, and identification of five infrequent mutations in the medium-chain acylCoA dehydrogenase gene in 55 patients with mediumchain acyl-CoA dehydrogenase deficiency. Am $\mathcal{f}$ Hum Genet 1991;47:1280-91.

3 Tanaka K, Yokota I, Coates PM, et al. Mutations in the medium-chain acyl-CoA dehydrogenase gene. Hum Mutat 1992;1:272-9.

4 Bennett MJ, Allison F, Pollitt RJ, et al. Fatty acid oxidation defects as causes of unexpected death in infancy, In Tanaka K, Coates PM, eds. Fatty acid oxidation: clinical, biochemical and molecular aspects. New York: Alan R Liss, 1990:349-64.

5 Matsubara Y, Narisawa K, Tada K. Medium-chain acylCoA dehydrogenase deficiency: molecular aspects. Eur $\mathcal{J}$ Pediatr 1992;151:154-9.

6 Miller ME, Brooks JG, Forbes N, et al. Frequency of medium-chain acyl-CoA dehydrogenase deficiency G-985 mutation in sudden infant death syndrome. Pediatr Res 1992;31:305-7.

7 Kelly DP, Hale DE, Rutledge SL, et al. Molecular basis of inherited medium-chain acyl-CoA dehydrogenase deficiency causing sudden infant child death. F Inher Metab

8 Coates PM, Hale DE, Stanley CA, et al. Genetic deficiency of medium-chain acyl coenzyme A dehydrogenase: studies in cultured skin fibroblasts and peripheral mononuclear leukocytes. Pediatr Res 1985;19:671-6.

9 Holmes Morton D, Kelly RI. Diagnosis of medium-chain acyl-coenzyme A dehydrogenase deficiency in the neonatal period by measurement of medium-chain fatty acids in plasma and filter paper blood samples. $\mathcal{F}$ Pediatr 1990 117:439-42.

10 Editorial. Medium chain acyl CoA dehydrogenase deficiency. Lancet 1991;338:544-5.

11 Millington DS, Kodo N, Norwood DL, Roe CR. Tandem mass spectrometry: a new method for acylcanitine profilin with potential for neonatal screening for inborn errors of metabolism. F Inher Metab Dis 1990;13:321-4.

12 Rinaldo P, O'Shea JJ, Coates PM, et al. Medium chain acylCoA dehydrogenase deficiency: diagnosis by stable-isotope dilution measurement of urinary n-hexanoylglycine and 3-phenylpropionylglycine. N Engl f Med 1988;319: 1308-13.

13 Coates PM, Stanley CA. Inherited disorders of mitochondrial fatty acid oxidation. In: Boyer JL, Ockner RK, eds. Progress in liver diseases. Vol X. Philadelphia: Saunders, 1992:123-38.

14 Kelly DP, Kim JJP, Billadello JJ, et al. Nucleotide sequence of medium-chain acyl-CoA dehydrogenase mRNA and its expression in enzyme-deficient human tissue. Proc Natl Acad Sci USA 1987;86:6677-81.

15 Zhang Z, Kelly DP, Kim JJ, et al. Structural organization and regulatory regions of the human medium-chain acyland regulatory regions of the human medium-chain acy

16 Matsubara Y, Narisawa K, Myabayashy S, et al. Identification of a common mutation in patients with medium-chain tion of a common mutation in patients with medium-chain acyl-CoA dehydrogenase de

17 Kelly DP, Whelan AJ, Ogden ML, et al. Molecular characterization of inherited medium-chain acyl-CoA dehydrogenase deficiency. Proc Natl Acad Sci USA 1990 87:9236-40.

18 Gregersen N, Andresen BS, Bross P, et al. Molecular characterization of the medium-chain acyl-CoA dehydrogenase MCAD) deficiency: identification of a $\mathrm{Lys}^{329}$ to Glu mutation in the MCAD gene, and expression of inactive mutant enzyme protein in E. coli. Hum Genet 1991;86:54551.

19 Matsubara Y, Narisawa K, Tada K, et al. Prevalence of $\mathrm{K} 329 \mathrm{E}$ mutation in medium-chain acyl-CoA dehydrogenase gene determined from Guthrie cards. Lance 1991;338:552-4.

20 Yokota I, Indo Y, Coates PM, et al. Molecular basis of medium chain acyl-coenzyme $A$ dehydrogenase deficiency. An $A$ to $G$ transition at position 985 that causes a lysine304 to glutamate substitution in the mature protein is the 
single prevalent mutation. $f$ Clin Invest 1990;86:1000-3.

21 Summers C, Fergusson W, Gokhale D, et al. Donor-recipient bone marrow matching by single-strand conformation polymorphism analysis. Lancet 1992;339:621.

22 Bannai M, Mazda T, Tokunaga K, et al. DNA single-strand conformation polymorphism method to distinguish DR4 alleles. Lancet 1993;341:769.

23 Orita $M$, Iwahana $H$, Kanazawa $H$, et al. Detection of polymorphisms of human DNA by gel electrophoresis as single-strand conformation polymorphism. Proc Natl Acad Sci USA 1989;86:2766-70.

24 Poncz M, Solowiejzcyk D, Harpel B, et al. Construction of human gene libraries from small amounts of peripheral blood: analyses of $\beta$-like globin genes. Hemoglobin 1982;6:27-33.

25 Saiki RK, Gelfand DH, Stoffel SJ, et al. Primer-directed enzymatic amplification of DNA with a thermostable DNA polymerase. Science 1987;239:487-91. 